\title{
ANALISIS KESESUAIAN LAHAN UNTUK RUANG TERBUKA HIJAU DAN RUANG TERBUKA BIRU DI SENTUL CITY, BOGOR
}

\section{Landscape Suitability \\ Analysis for Green Open \\ Spaces and Blue Open \\ Spaces in Sentul City, \\ Bogor}

\section{Erlinda Faradilla}

Mahasiswa Departemen

Arsitektur Lanskap,

Fakultas Pertanian IPB

\section{Kaswanto}

Staf Pengajar Departemen

Arsitektur Lanskap,

Fakultas Pertanian IPB

\section{Hadi Susilo Arifin}

Staf Pengajar Departemen

Arsitektur Lanskap,

Fakultas Pertanian IPB

\begin{abstract}
Sentul City as a new city must be able to meet the water needs of its residents. Sentul City has annual rainfall up to $4000 \mathrm{~mm} /$ year but most are rare groundwater areas. With the topography, its annual rainfall, and proximity to the river, Sentul City is a good potential for maintain the green and blue open spaces in order to harvest rainwater and stormwater. Analysis of land suitability of green and blue open spaces is needed to optimizing the land use of Sentul City. This study was aimed to do land suitability analysis of green and blue open spaces in Sentul City. The research is conducted by land evaluation method using Geographic Information System (GIS). The analysis result shows that land that are suitable for park, urban forest, dan very suitable for lake are $78.20 \%, 52.59 \%$, dan $3.70 \%$ of the total area.
\end{abstract}

Keywords: blue open spaces, green open spaces, land suitability

\section{PENDAHULUAN}

Air adalah sumber kehidupan. Permasalahan yang terjadi saat ini adalah telah terjadi krisis air, dengan faktor utama perilaku manusia. Pada kawasan perkotaan, telah terjadi konflik kepentingan dan kebutuhan antara man versus water; konflik ruang terbangun versus ruang terbuka hijau; konflik tata ruang bangunan versus tata ruang air. Peningkatan ruang terbangun menyebabkan pengurangan ruang terbuka hijau dalam jumlah besar sehingga banyak lahan hijau, situ, daerah resapan, dan tempat tinggal air menjadi hilang (Kodoatie dan Sjarief 2008). Oleh karena itu, pengelolaan ruang terbuka di kawasan perkotaan untuk menjaga baik kuantitas maupun kualitas air sangat penting dilakukan.

Sentul City merupakan kota mandiri di Kabupaten Bogor yang dikembangkan oleh PT Sentul City Tbk. Sentul City mengembangkan kawasannya dengan prinsip green development. Konsep pengembangan kawasan Sentul City dituangkan dalam rencana induk yang membagi kawasan Sentul City menjadi dua area, yaitu area bangunan dan tutupan jalan, serta area konservasi. Area konservasi yang direncanakan berupa hutan kota, taman, taman bermain, dan danau buatan, seperti yang tertuang dalam Masterplan Sentul City tahun 2011 (Sentul City 2011). Sentul City berkomitmen untuk menjaga keseimbangan antara ruang terbangun dengan ruang terbuka. Lahan dengan bentuk wilayah datar hingga bergelombang lemah pada bagian barat dan utara akan dibangun untuk hunian kepadatan sedang dengan koefisien dasar bangunan (KDB) 60\%, sedangkan lahan yang bergelombang kuat dan berbukit pada bagian timur dan selatan akan dibangun untuk hunian kepadatan rendah dengan KDB 30\% (Sentul City 2012a). Kawasan Sentul City sering kali mengalami permasalahan suplai air. Suplai air bersih untuk kawasan Sentul City yang berasal dari PDAM Kabupaten Bogor sering kali terkendala akibat debit air yang kecil, maupun adanya gangguan teknis untuk penyaluran air bersih. Selain itu, pelayanan PDAM untuk wilayah Kabupaten Bogor baru mencapai 41.7\% dari total yang harus dilayani (Bappeda 2007).

Sentul City sebagai kota mandiri seharusnya dapat memenuhi kebutuhan air bagi penduduk di kawasannya. Penelitian terbaru mengenai pengelolaan air di perkotaan memiliki kerangka pikir tahap transisi kota menuju water sensitive city (WSC) atau kota sensitif air. WSC adalah proses kontinyu tahap pengelolaan air perkotaan, yang terdiri atas water supply city, sewered city, drained city, waterways city, water cycle city, dan water sensitive city. Tahap pertama dalam proses pengelolaan air di perkotaan adalah water supply city. Tahap ini adalah tahap di mana kota sebagai penyedia air dapat memenuhi kebutuhan air penduduknya, baik air untuk diminum maupun air untuk keperluan lain (Wong et al. 2013). WSC atau kota sensitif air adalah tujuan akhir yang ingin dicapai. Oleh karena itu, upaya pemenuhan kebutuhan air di Sentul City sebagai transisi menuju kota sensitif air sangatlah penting.

Upaya pemenuhan kebutuhan air ini dapat dilakukan dengan upaya menampung air hujan dan limpasan 
permukaan, yaitu dengan teknik pemanenan rainwater maupun stormwater. Pengelolaan dan pemanenan air hujan menjadi kesempatan signifikan untuk menyediakan sumber air baru yang utama untuk digunakan oleh kota, sekaligus membantu melindungi saluran air yang penting dari polusi dan degradasi ekosistem yang berlebihan (PMSEIC 2017 dalam Wong et al. 2013). Air hujan yang ditampung merupakan salah satu bentuk sumber daya air yang dapat digunakan untuk kebutuhan air domestik, industri, pertanian, dan peternakan (BSNI 2002). Usaha pemanenan air hujan seharusnya diprioritaskan untuk daerah yang mengalami intensitas hujan cukup tinggi (Asdak 1995). Kawasan Sentul City termasuk dalam wilayah dengan potensi curah hujan yang sangat tinggi dan sifat hujan di atas normal (BMKG Darmaga 2016). Dengan demikian, upaya pemanenan air hujan sangat sesuai dilakukan di Sentul City.

Upaya menampung air hujan dan air limpasan permukaan di Sentul City dapat dilakukan dengan memanfaatkan area yang direncanakan pihak pengembang kota sebagai area konservasi berupa ruang terbuka hijau (RTH) dan ruang terbuka biru (RTB). Jenis RTH dan RTB yang direkomendasikan dalam kajian ini adalah hutan kota, taman, dan danau. Berdasarkan permasalahan dan potensi kawasan, Sentul City memiliki potensi untuk dapat melakukan pengelolaan air dengan memanfaatkan lahan RTH dan RTB sebagai daerah tampungan air. Saat ini, Sentul City masih berada dalam tahap pembangunan sehingga masih mungkin mempertahankan ruang terbuka yang ada. Oleh karena itu, penelitian ini bertujuan untuk menganalisis lahan yang sesuai untuk dimanfaatkan sebagai RTH dan RTB di kawasan perkotaan Sentul City, dalam bentuk taman, hutan kota, dan danau.

\section{METODE PENELITIAN}

\section{Waktu dan Lokasi Penelitian}

Penelitian dilakukan di Sentul City, Kabupaten Bogor. Sentul City terletak pada koordinat 6 $6^{\circ} 33^{\prime} 55^{\prime \prime}-6^{\circ} 38^{\prime} 10^{\prime \prime}$ LS dan 106 50' 40" - 106 55' 40" BT (Gambar 1). Penelitian dilakukan selama enam bulan, yaitu dari bulan Februari hingga Juli 2017.

\section{Evaluasi Lahan untuk Ruang Terbuka Hijau dan Ru- ang Terbuka Biru}

Tujuan evaluasi lahan adalah untuk menentukan lahan yang sesuai untuk RTH dan RTB kawasan perkotaan berupa taman, hutan kota, dan danau. Pendekatan delineasi satuan peta lahan yang digunakan adalah pendekatan sistem informasi geografis. Bahan yang digunakan meliputi peta batas administrasi, peta batas kawasan, peta jenis tanah, peta geologi, data iklim, dan kriteria kesesuaian lahan. Proses evaluasi dilakukan dengan matching, yaitu membandingkan kualitas lahan

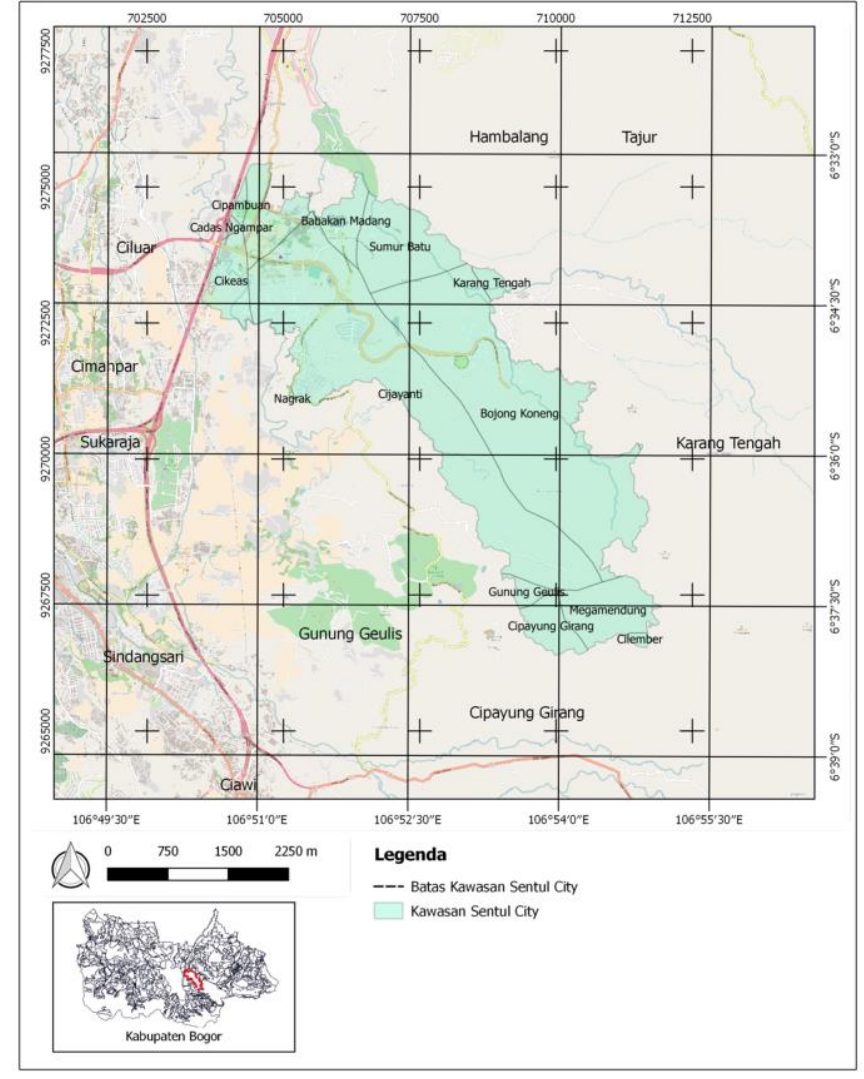

Gambar 1. Peta lokasi penelitian

dengan kriteria kesesuaian lahan untuk RTH dan RTB. Berdasarkan proses matching tersebut, dihasilkan peta kesesuaian lahan untuk masing-masing RTH dan RTB. Taman merupakan salah satu bentuk RTH kawasan perkotaan yang memiliki nilai koefisien run off yang sangat rendah hingga rendah, yaitu $0.10-0.25$. Nilai tersebut termasuk dalam kelas koefisien run off sangat rendah dan rendah. Taman dapat didesain secara spesifik untuk mengelola aliran permukaan stormwater dari berbagai sumber seperti atap bangunan, jalan raya, lapangan rumput, jalan setapak, area parkir, dengan membentuk lahan basah dan penggunaan tanaman yang toleran terhadap air. Selama hujan, taman akan dipenuhi air hujan, kemudian air secara perlahan akan meresap ke dalam tanah dan mengurangi aliran permukaan, dan pada akhirnya akan meningkatkan ketersediaan air tanah. Taman lingkungan yang didesain secara spesifik untuk mengelola stormwater dan diintegrasikan dengan sistem bioretensi, sumur resapan, cekungan infiltrasi, paving yang dapat menyerap air, penyaring tanah, tanaman penyaring, dan rumput disebut sebagai sebagai rain park (Wright 2015).

Salah satu jenis RTH kawasan perkotaan yang dapat meningkatkan ketersediaan air tanah adalah hutan kota. Hutan kota memiliki derajat kerembesan tanah yang lebih tinggi dibandingkan jenis permukaan tanah lainnya (Ruliyansyah 2009). Hutan memiliki nilai koefisien run off $(C)$ sebesar 0.5-0.2. Ini berarti air hujan 
yang jatuh akan lebih banyak terserap ke dalam tanah daripada yang mengalir sebagai aliran permukaan (Asdak 1995). Pada Rencana Tata Ruang Wilayah (RTRW) Kabupaten Bogor Tahun 2005-2025 terdapat lahan di Sentul City yang ditetapkan sebagai hutan oleh pemerintah berdasarkan karakteristik lahan, yaitu kelas lereng, ketinggian, dan kemampuan tanah. Dengan demikian, hutan kota menjadi rekomendasi yang dapat diterapkan di Sentul City sebagai bentuk RTH yang berfungsi untuk meningkatkan ketersediaan air tanah dalam upaya meningkatkan suplai air.

RTB untuk menampung air hujan di kawasan perkotaan dapat dirancang dalam bentuk danau buatan atau kolam retensi. Danau buatan dapat diterapkan di kawasan perumahan, sementara kolam retensi khusus diterapkan di sempadan sungai. Selain berfungsi sebagai sumber daya air, danau juga dapat mengkonservasi biodiversitas flora dan fauna, meningkatkan serapan karbon, meningkatkan efek pendinginan udara, dan meningkatkan keindahan lanskap. Selain itu, kawasan Sentul City yang memiliki bentuk wilayah bergelombang hingga berbukit sangat sesuai untuk didesain sebagai cekungan badan air. Oleh karena itu, danau buatan menjadi rekomendasi yang dapat diterapkan di Sentul City sebagai bentuk RTB yang berfungsi untuk menampung air hujan.

\section{Analisis Kesesuaian Lahan untuk Taman}

Kesesuaian lahan untuk taman adalah kesesuaian lahan untuk daerah taman yang secara insentif digunakan untuk piknik, bersantai, dan makan-makan di luar rumah (Hardjowigeno dan Widiatmaka 2007). Kriteria kesesuaian lahan untuk daerah piknik menunjukkan sifat-sifat suatu lahan yang mempengaruhi kesesuaian lahan untuk taman. Sifat-sifat tanah tersebut adalah tekstur tanah, drainase tanah, kemiringan lahan, kerikil dan kerakal, batu, batuan, dan bahaya banjir. Karakteristik drainase tanah yang baik untuk taman adalah drainase tanah yang cepat, agak cepat, baik dan agak baik, serta air tanah lebih dari $50 \mathrm{~cm}$, sedangkan drainase tanah yang jelek, sangat jelek, dan air tanah kurang dari $50 \mathrm{~cm}$ sampai dekat dengan permukaan merupakan drainase tanah yang buruk untuk taman. Lahan yang baik untuk taman adalah taman yang tidak memiliki bahaya banjir, sedangkan lahan yang berpotensi banjir lebih dari dua kali selama musim piknik merupakan lahan yang buruk untuk taman (USDA 1968 dalam Hardjowigeno dan Widiatmaka 2007). Kemiringan lahan yang baik untuk taman adalah 0-8\%, sedangkan kemiringan lahan lebih besar dari 15\% buruk untuk taman. Tekstur permukaan tanah yang baik untuk taman adalah kelompok sedang, yaitu lempung berpasir, lempung berpasir halus, lempung berpasir sangat halus, lempung, dan lempung berdebu. Tekstur permukaan tanah yang buruk untuk taman adalah kelompok halus, yaitu liat berpasir, liat berdebu, dan liat. Banyaknya kerikil dan kerakal yang baik untuk taman adalah 0-20\%. Apabila kerikil dan kerakal banyaknya lebih besar dari $50 \%$, lahan tersebut termasuk lahan yang buruk untuk dimanfaatkan sebagai taman. Apabila lahan memiliki batu sebanyak 0-3\%, lahan tersebut baik untuk dimanfaatkan sebagai taman. Lahan yang memiliki batu sebanyak lebih besar dari 15\% termasuk lahan yang buruk untuk dimanfaatkan sebagai taman. Jumlah batuan dalam suatu lahan yang baik untuk taman adalah $0-0.01 \%$, dan lahan dengan batuan lebih dari 3\% tidak baik untuk taman (USDA 1968 dalam Hardjowigeno dan Widiatmaka 2007).

Berdasarkan sifat-sifat tanah di atas, disusun kriteria kelas kesesuaian lahan untuk taman. Kelas kesesuaian lahan dikelompokkan ke dalam empat kelas, yaitu sangat sesuai (S1), cukup sesuai (S2), sesuai marjinal (S3), dan tidak sesuai (N). Kualitas lahan untuk taman dikelompokkan ke dalam tiga kelas, yaitu media perakaran $(\mathrm{r})$, potensi mekanisasi $(\mathrm{m})$, dan bahaya banjir (i). Karakteristik lahan yang mempengaruhi kualitas media perakaran adalah tekstur dan drainase tanah. Karakteristik lahan yang mempengaruhi kualitas potensi mekanisasi adalah kemiringan lahan, kerikil dan kerakal, batu, dan batuan. Kelas kesesuaian lahan yang sangat sesuai (S1) untuk taman adalah lahan yang memiliki tekstur tanah sedang, drainase tanah cepat dan agak cepat, kemiringan lahan $0-8 \%$, kerikil dan kerakal sebanyak $0-15 \%$, batu sebanyak $0-3 \%$, dan batuan 0 $0.01 \%$, dan tidak pernah terjadi bahaya banjir sepanjang tahun. Sebaliknya, lahan yang tidak sesuai $(\mathrm{N})$ untuk taman adalah lahan yang memiliki tekstur tanah kasar, drainase tanah sangat jelek, kemiringan lahan lebih besar dari $25 \%$, kerikil dan kerakal lebih besar dari 50\%, batu lebih besar dari 15\%, batuan lebih besar dari 3\%, dan sangat sering terjadi banjir, yaitu banjir selama 2-6 bulan dalam satu tahun (Tabel 1).

\section{Analisis Kesesuaian Lahan untuk Hutan Kota}

Faktor penciri yang digunakan untuk menentukan kesesuaian lahan untuk penatagunaan hutan meliputi kemiringan lereng, faktor jenis tanah menurut kepekaannya terhadap erosi, dan faktor curah hujan. Masing-masing faktor diberi penilaian untuk menentukan tipe hutan yang akan direncanakan, yaitu hutan lindung, hutan suaka alam, hutan wisata, hutan konservasi lain, hutan produksi terbatas, atau hutan produksi bebas. Hutan lindung adalah areal lahan dengan jumlah hasil penilaian lebih dari 175, hutan produksi terbatas adalah areal dengan nilai 125-174, dan hutan produksi bebas adalah areal dengan nilai lebih kecil dari 124. Penilaian terhadap hutan suaka alam, hutan wisata, dan hutan konservasi lain tidak didasarkan atas jumlah nilai dari faktor fisik tersebut, tetapi didasarkan atas kekhasan masing-masing hutan sesuai dengan tujuan konservasi tersebut (Hardjowigeno dan Widiatmaka 2007). Hutan kota termasuk ke dalam 


\section{FARADILLA, KASWANTO, ARIFIN}

hutan wisata. Dengan demikian, analisis kesesuaian lahan tidak dilakukan berdasarkan penilaian (scoring), tetapi dilakukan klasifikasi kelas kesesuaian lahan terhadap karakteristik lahan. Faktor curah hujan tidak diklasifikasikan kelas kesesuaiannya karena seluruh kawasan Sentul City memiliki curah hujan sangat tinggi. Dalam penilaian kesesuaian lahan untuk hutan tersebut, faktor lereng diberikan penilaian sebagai berikut: 1) kelas 1 dengan kemiringan $0-8 \%$ (datar) bernilai 20, 2) kelas 2 dengan kemiringan 8-15\% (landai) bernilai 40, 3) kelas 3 dengan kemiringan 15-25\% (agak curam) bernilai 60 , 4) kelas 4 dengan kemiringan $25-40 \%$ (curam) bernilai 80, dan 5) kelas 5 dengan kemiringan lebih besar dari $40 \%$ (sangat curam) bernilai 100. Pada penilaian tersebut, semakin tinggi kemiringan lereng, semakin besar nilainya karena diperuntukkan bagi hutan lindung. Hutan kota yang direkomendasikan dalam penelitian ini adalah hutan kota yang juga memiliki fungsi rekreasi di dalam kota sehingga faktor kelerengan menjadi faktor keamanan bagi pengguna. Dengan demikian, kemiringan lahan $0-15 \%$ menjadi karakteristik lahan yang sangat sesuai untuk hutan kota, kemiringan $15-25 \%$ cukup sesuai, kemiringan $25-45 \%$ sesuai marjinal, sedangkan kemiringan lahan lebih besar

Tabel 1 Kriteria kelas kesesuaian lahan untuk taman

\begin{tabular}{|c|c|c|c|c|c|}
\hline & \multirow{2}{*}{$\begin{array}{l}\text { Kualitas dan } \\
\text { Karakteristik Lahan }\end{array}$} & \multicolumn{4}{|c|}{ Kelas Kesesuaian Lahan } \\
\hline & & S1 & S2 & S3 & $\mathrm{N}$ \\
\hline I & Media perakaran (r) & & & & \\
\hline 1 & Tekstur & Sedang & Agak halus & Halus & Kasar \\
\hline 2 & Drainase tanah & $\begin{array}{l}\text { Cepat, agak } \\
\text { cepat }\end{array}$ & Baik, agak baik & Agak jelek, jelek & Sangat jelek \\
\hline II & Potensi mekanisasi (m) & & & & \\
\hline 1 & Kemiringan lahan & $0-8 \%$ & $8-15 \%$ & $15-25 \%$ & $>25 \%$ \\
\hline 2 & $\begin{array}{l}\text { Kerikil dan kerakal (2 } \\
\mathrm{mm}-25 \mathrm{~cm})\end{array}$ & $0-15 \%$ & $15-30 \%$ & $30-50 \%$ & $>50 \%$ \\
\hline 3 & Batu $(>25 \mathrm{~cm})$ & $0-3 \%$ & $3-10 \%$ & $10-15 \%$ & $>15 \%$ \\
\hline 4 & Batuan (bedrock) $(>60)$ & $0-0.01 \%$ & $0.1-2 \%$ & $2-3 \%$ & $>3 \%$ \\
\hline III & Bahaya banjir (i) & Tidak pernah & Jarang & Kadang-kadang & $\begin{array}{l}\text { Sering dan sangat } \\
\text { sering }\end{array}$ \\
\hline
\end{tabular}

Sumber: Hardjowigeno dan Widiatmaka (2007) dimodifikasi

Tabel 2 Kriteria kelas kesesuaian lahan untuk hutan kota

\begin{tabular}{|c|c|c|c|c|c|}
\hline & \multirow{2}{*}{$\begin{array}{l}\text { Kualitas dan } \\
\text { Karakteristik } \\
\text { Lahan }\end{array}$} & \multicolumn{4}{|c|}{ Kelas Kesesuaian Lahan } \\
\hline & & S1 & S2 & S3 & $\mathrm{N}$ \\
\hline I & Bahaya erosi (e) & & & & \\
\hline \multirow[t]{2}{*}{1} & $\begin{array}{l}\text { Kepekaan } \\
\text { terhadap erosi }\end{array}$ & Sangat peka & Peka & $\begin{array}{l}\text { Agak peka, kurang } \\
\text { peka }\end{array}$ & Tidak peka \\
\hline & & $\begin{array}{l}\text { Regosol, litosol, } \\
\text { organosol, } \\
\text { rendzina }\end{array}$ & $\begin{array}{l}\text { Andosol, laterik, } \\
\text { grumosol, posol, } \\
\text { podsolik }\end{array}$ & $\begin{array}{l}\text { Latosol, Brown } \\
\text { forest soil, non } \\
\text { calcin brown, } \\
\text { mediteran }\end{array}$ & $\begin{array}{l}\text { Aluvial, planosol, } \\
\text { hidromorf kelabu, } \\
\text { laterit air tanah }\end{array}$ \\
\hline II & Media perakaran (r) & & & & \\
\hline 1 & Drainase tanah & $\begin{array}{l}\text { Cepat, agak } \\
\text { cepat }\end{array}$ & Baik, agak baik & Agak jelek, jelek & Sangat jelek \\
\hline 2 & Kedalaman efektif & $\begin{array}{l}\text { Sangat dalam } \\
(>150 \mathrm{~cm})\end{array}$ & $\begin{array}{l}\text { Dalam (120-150 } \\
\mathrm{cm})\end{array}$ & $\begin{array}{l}\text { Sedang }(100-120 \\
\mathrm{cm}) \text {, Dangkal } \\
(<100) \mathrm{cm}\end{array}$ & $\begin{array}{l}\text { Sangat dangkal }(< \\
60 \mathrm{~cm})\end{array}$ \\
\hline III & \multicolumn{5}{|l|}{ Potensi mekanisasi (m) } \\
\hline 1 & Kemiringan lahan & $0-15 \%$ & $15-25 \%$ & $25-45 \%$ & $>45 \%$ \\
\hline
\end{tabular}

Sumber: Hardjowigeno dan Widiatmaka (2007) dimodifikasi 
dari $45 \%$ tidak sesuai untuk hutan kota.

Dalam penilaian kesesuaian lahan untuk hutan tersebut, faktor kepekaan tanah terhadap erosi diberikan penilaian sebagai berikut: 1) kelas 1 dengan tanah tidak peka terhadap erosi bernilai 15,2) kelas 2 dengan tanah agak peka terhadap erosi bernilai 30,3) kelas 3 dengan tanah kurang peka terhadap erosi bernilai 45,4$)$ kelas 4 dengan tanah peka terhadap erosi bernilai 60,5 ) dan kelas 5 dengan tanah sangat peka terhadap erosi bernilai 75. Pada penilaian tersebut, semakin tinggi kepekaan tanah terhadap erosi, semakin sesuai lahan tersebut untuk dimanfaatkan sebagai hutan. Tanah yang kepekaan terhadap erosinya tinggi lebih mudah mengalami erosi sehingga sangat sesuai untuk menjadi area konservasi. Dengan demikian, jenis tanah yang sangat peka erosi menjadi karakteristik lahan yang sangat sesuai untuk hutan kota, tanah yang peka erosi termasuk cukup sesuai, tanah yang agak peka dan kurang peka erosi termasuk sesuai marjinal, sedangkan jenis tanah yang tidak peka erosi termasuk tidak sesuai untuk hutan kota.

Kesesuaian lahan untuk tanaman yang akan ditanam dalam hutan kota juga memerlukan kualitas lahan tertentu. Kualitas lahan yang dianalisis adalah media perakaran untuk tanaman tahunan, dengan karakteristik drainase dan kedalaman efektif tanah. Lahan yang sangat sesuai untuk hutan kota adalah lahan yang memiliki drainase cepat. Semakin jelek drainasenya maka semakin tidak sesuai. Kedalaman efektif yang sangat dalam menjadi lahan yang sangat sesuai, sementara kedalaman efektif yang sangat dangkal termasuk lahan yang tidak sesuai. Dengan demikian, kelas kesesuaian lahan yang sangat sesuai (S1) untuk hutan kota adalah lahan yang sangat peka terhadap erosi, memiliki drainase tanah yang cepat, kedalaman efektif tanah sangat dalam, dan kemiringan lahan kurang dari $15 \%$. Sebaliknya, lahan yang tidak sesuai (N) untuk hutan kota adalah lahan yang tidak peka terhadap erosi, memiliki drainase tanah yang sangat jelek, kedalaman efektif tanah sangat dangkal, dan kemiringan lahan lebih besar dari 45\% (Tabel 2).

\section{Analisis Kesesuaian Lahan untuk Danau}

Analisis ini dilakukan untuk mendapatkan kesesuaian lahan untuk danau buatan sebagai tempat menampung air atau reservoir dengan teknik pemanenan air hujan. Faktor yang mempengaruhi kesesuaian lahan untuk pemanenan air hujan adalah faktor curah hujan, tekstur permukaan tanah, kedalaman tanah, topografi, tutupan vegetasi, dan pola drainase. Semakin tinggi curah hujan pada suatu lahan maka semakin besar potensi untuk melakukan pemanenan air hujan. Tekstur permukaan tanah adalah karakteristik tanah yang penting dalam pemanenan air hujan. Tekstur tanah menentukan infiltrasi dan penyimpanan air di dalam tanah. Tekstur permukaan tanah yang halus dan agak halus lebih sesuai untuk pemanenan air hujan karena kemampuannya dalam menahan air dan nutrisi. Tanah dengan presentase partikel debu dan liat yang lebih tinggi akan memiliki kapasitas menahan air yang lebih tinggi. Hal ini penting karena kapasitas air dalam menahan air adalah sifat tanah yang penting dalam teknik pemanenan air hujan. Tanah yang mengandung partikel liat lebih banyak lebih sesuai untuk menampung air. Hal ini disebabkan oleh drainase tanah yang jelek dan kapasitas menahan air yang tinggi dari tanah liat (Tumbo et al. 2014).

Penerapan daerah tampungan air ini sesuai untuk dilakukan pada lahan dengan kemiringan lahan besar. Area dengan kemiringan lereng yang tinggi yaitu $10^{\circ}$ $30^{\circ}$ lebih sesuai untuk menampung air, karena air dapat lebih mudah untuk mengalir dengan adanya gravitasi (Tumbo et al. 2014). Besarnya air hujan yang dapat ditampung atau dipanen bervariasi dari sekitar 30\% dari total hujan untuk kondisi permukaan bidang tangkapan yang bersifat tidak kedap air dan dalam keadaan datar, sampai dengan lebih dari $90 \%$ untuk keadaan bidang tangkapan yang berlereng dan bersifat kedap air. Pembuatan daerah tampungan pada kemiringan lereng besar seringkali hanya memerlukan pemadatan permukaan tanah yang dilakukan dengan hati-hati untuk kemudian siap digunakan sebagai sarana pemanenan air hujan, sedangkan pada bidang tangkapan yang relatif datar perlu dibuat unit-unit bidang tangkapan air hujan yang lebih kecil dan dilengkapi saluran air (Asdak 1995). Hal ini juga sesuai untuk penerapan danau buatan di bagian perumahan dan komersial kawasan, dengan memanfaatkan lahan yang not saleable untuk perumahan, yaitu pada lahan yang memiliki kemiringan tinggi. Selain itu, apabila terjadi kelebihan atau luapan air pada danau buatan, air dapat dialirkan ke sungai atau saluran tersebut.

Tempat penampungan air lebih sesuai pada lahan yang lebih dekat dengan saluran sungai atau drainase untuk dapat mengalirkan air. Daerah tampungan air paling sesuai berada pada jarak 0-125 meter dengan sungai atau saluran, sesuai pada jarak 0-350 meter, dan tidak sesuai pada jarak lebih dari 500 meter. Daerah tampungan air paling sesuai diterapkan pada daerah tutupan vegetasi yang rendah (Tumbo et al. 2014). Air hujan yang dipanen akan lebih banyak tertangkap pada daerah dengan tutupan vegetasi rendah. Tutupan vegetasi yang rendah lebih sesuai untuk pemanenan air hujan karena laju infiltrasi di tempat bidang tangkapan air hujan tersebut menjadi lebih rendah (Asdak 1995). Dengan demikian, air hujan akan lebih banyak yang ditampung dalam daerah tampungan air sehingga dapat menjadi salah satu sumber daya air dalam bentuk blue water.

Kelas kesesuaian lahan untuk danau sebagai tempat menampung air dikelompokkan atas lahan yang sangat sesuai (S1), cukup sesuai (S2), sesuai marjinal (S3), dan tidak sesuai $(\mathrm{N})$. Karakteristik tanah yang digunakan 
untuk menganalisis kesesuaian lahan terdiri atas tekstur permukaan tanah, kemiringan lahan, jarak ke sungai, dan penutupan lahan. Kelas lahan yang paling sesuai adalah lahan yang memiliki tekstur halus, meliputi liat berdebu dan liat, kemiringan lahan $10-30^{\circ}$, penutupan lahan semak belukar, dan jarak ke sungai kurang dari 250 meter. Sebaliknya, kelas lahan yang tidak sesuai adalah lahan yang memiliki tekstur permukaan tanah pasir maupun kerikil, kemiringan lahan kurang dari $2^{\circ}$, penutupan lahan berupa vegetasi riparian, dan jarak ke sungai lebih dari 500 meter (Tabel 3). permukaan liat yang bersifat lekat dan memiliki porpori kecil atau tidak porous menyebabkan tanah sulit meresapkan air ke dalam tanah (Hanafiah 2005). Akibatnya adalah tanah akan mudah digenangi air. Untuk mencegah terjadinya genangan banjir, dapat dilakukan pembuatan saluran drainase yang memadai pada lahan yang sesuai marjinal sebagai taman.

Kelas lahan yang terbesar kedua adalah lahan sesuai marjinal dengan faktor pembatas tekstur tanah dan lereng (S3r-1.s), yaitu sebesar 509.22 ha (17.60\%). Kelompok lahan ini memiliki faktor pembatas tekstur tanah dan termasuk dalam kelas lereng 15-25\%.

Tabel 3 Kriteria kesesuaian lahan untuk danau

\begin{tabular}{|c|c|c|c|c|c|}
\hline & \multirow{2}{*}{$\begin{array}{c}\text { Kualitas dan Karakteristik } \\
\text { Lahan }\end{array}$} & \multicolumn{4}{|c|}{ Kelas Kesesuaian Lahan } \\
\hline & & S1 & S2 & S3 & $\mathrm{N}$ \\
\hline I & Media perakaran $(\mathrm{r})$ & & & & \\
\hline 1 & Tekstur permukaan tanah & $\begin{array}{l}\text { liat berdebu, } \\
\text { liat }\end{array}$ & $\begin{array}{l}\text { lempung liat, } \\
\text { liat berpasir }\end{array}$ & $\begin{array}{l}\text { lempung liat } \\
\text { berdebu, lempung } \\
\text { liat berpasir }\end{array}$ & $\begin{array}{l}\text { Kerikil dan } \\
\text { pasir }\end{array}$ \\
\hline II & Potensi mekanisasi (m) & & & & \\
\hline 1 & Kemiringan lahan $\left({ }^{\circ}\right)$ & $10-30$ & $5-10$ & $2-5$ & $<2$ \\
\hline 2 & Penutupan lahan & Semak belukar & $\begin{array}{l}\text { Semak belukar } \\
\text { dengan pohon } \\
\text { tersebar }\end{array}$ & $\begin{array}{l}\text { Hutan dengan } \\
\text { semak belukar }\end{array}$ & $\begin{array}{l}\text { Vegetasi } \\
\text { sungai }\end{array}$ \\
\hline III & Ketersediaan air (w) & & & & \\
\hline 1 & Jarak ke sungai $(\mathrm{m})$ & $0-250$ & $250-350$ & $350-500$ & $>500$ \\
\hline
\end{tabular}

Sumber: Tumbo et al. (2014) dimodifikasi

\section{HASIL DAN PEMBAHASAN}

\section{Analisis Kesesuaian Lahan untuk Taman}

Berdasarkan hasil penilaian analisis kesesuaian lahan untuk RTH taman pada area kajian, diperoleh kelas kesesuaian aktual sesuai marjinal (S3) dan tidak sesuai (N) (Gambar 2). Tidak terdapat lahan yang benar-benar sangat sesuai untuk taman pada area kajian. Luasan lahan terbesar adalah lahan yang termasuk ke dalam kelas kesesuaian S3r-1, yaitu sebesar 2116.08 ha (73.12\%). Lahan ini terdapat menyebar di seluruh area kajian. Lahan tersebut adalah kelas lahan yang sesuai marginal untuk taman dengan faktor pembatas tekstur permukaan tanah. Tekstur permukaan tanah di Sentul City adalah liat dan tergolong kelas halus sehingga menjadi faktor pembatas lahan.

Usaha perbaikan karakteristik lahan untuk meningkatkan kelas kesesuaian lahan aktual menjadi potensial tidak dapat dilakukan pada faktor pembatas tekstur permukaan tanah. Kesesuaian lahan aktual adalah kesesuaian lahan yang belum mempertimbangkan usaha perbaikan dan tingkat pengelolaan yang dapat dilakukan untuk mengatasi faktor pembatas yang ada pada lahan. Kesesuaian lahan potensial adalah kesesuaian lahan yang akan dicapai setelah dilakukan usaha perbaikan lahan tanah (Hardjowigeno dan Widiatmaka 2007). Tekstur

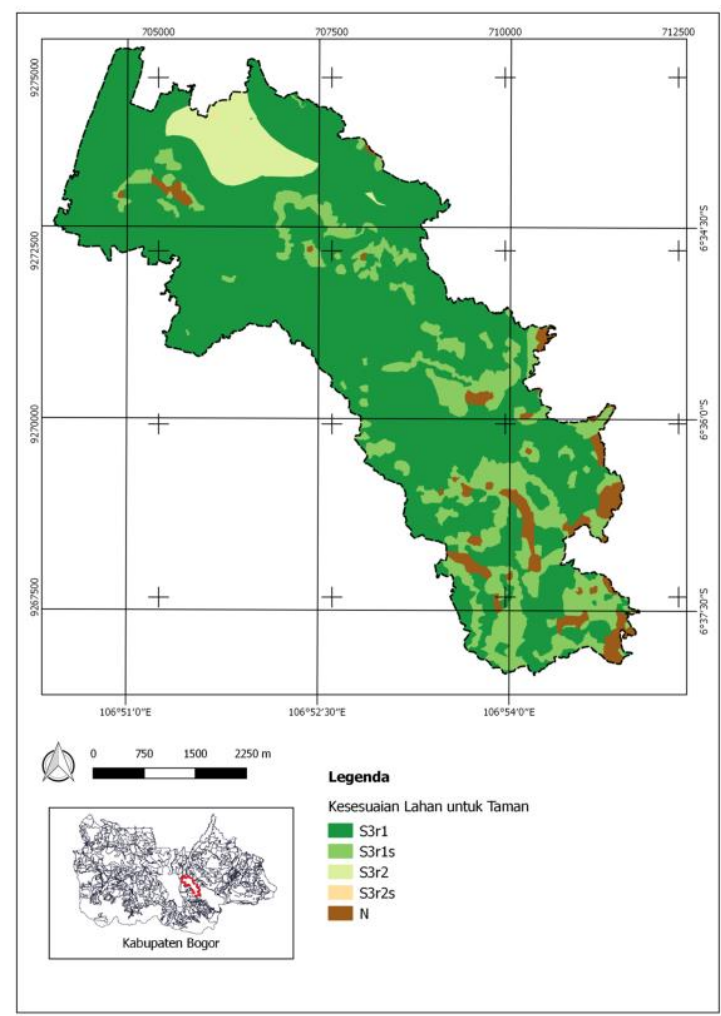

Gambar 2 Peta kesesuaian lahan untuk taman 
Kelerengan ini menyebabkan perlunya upaya mekanisasi berupa grading sehingga lahan ini tidak direkomendasikan untuk pemanfaatan sebagai taman. Kelas lahan dengan faktor pembatas drainase tanah (S3r2) juga dijumpai pada area kajian, yaitu seluas 146.94 ha (5.08\%). Upaya perbaikan dapat dilakukan pada kelas lahan ini, yaitu dengan membuat sistem drainase yang baik. Terdapat sebagian kecil lahan yang termasuk dalam kelas sesuai marjinal dengan faktor pembatas drainase tanah dan lereng (S3r-2.s), yaitu seluas 0.60 ha $(0.02 \%)$. Kelas lahan ini tidak direkomendasikan karena dibutuhkan upaya mekanisasi lahan berupa grading. Kelas lahan yang tidak sesuai untuk taman terdapat pada lahan dengan kelas lereng lebih besar dari $25 \%$. Lahan yang tidak sesuai tersebut $(\mathrm{N})$ adalah sebesar 121.20 ha (4.19\%) (Tabel 4). Dengan demikian, lahan yang potensial sebagai taman adalah kelas lahan S3r-1 seluas $73.12 \%$ dan S3r-2 seluas $5.08 \%$, dengan upaya perbaikan berupa pembuatan sistem drainase yang baik.

\section{Analisis Kesesuaian Lahan untuk Hutan Kota}

Berdasarkan hasil penilaian evaluasi kesesuaian lahan untuk RTH hutan kota pada area kajian, diperoleh kelas kesesuaian sesuai marjinal (S3) dan tidak sesuai (N) (Gambar 3). Tidak terdapat lahan yang benar-benar sangat sesuai untuk hutan kota pada area kajian. Luasan lahan terbesar adalah lahan yang termasuk ke dalam kelas kesesuaian S3r, yaitu sebesar 1522.10 ha (52.59\%). Lahan ini terdapat menyebar di seluruh area kajian. Lahan tersebut adalah kelas lahan yang sesuai marginal untuk hutan kota dengan faktor pembatas kedalaman efektif tanah. Kedalaman efektif tanah di Sentul City berkisar antara 60 hingga $90 \mathrm{~cm}$ sehingga termasuk dalam kelas kedalaman efektif sesuai marjinal. Dengan faktor pembatas kedalaman efektif tanah, umumnya tidak dapat dilakukan upaya perbaikan, kecuali pada lapisan padas lunak dan tipis dengan membongkarnya waktu pengolahan tanah (Hardjowigeno dan Widiatmaka 2007). Kelas lahan ini memiliki kepekaan terhadap erosi sehingga sangat sesuai untuk dimanfaatkan sebagai hutan dengan adanya usaha pengurangan laju erosi berupa penanaman.

Kelas lahan kedua terbesar adalah lahan sesuai marjinal dengan faktor kedalaman efektif tanah dan kepekaan terhadap erosi (S3er), yaitu sebesar 846.25 ha (29.24\%). Kelompok lahan ini memiliki faktor pembatas kedalaman efektif tanah yang sedang maupun dangkal, dan jenis tanah kurang peka terhadap erosi. Kelas lahan dengan faktor pembatas kedalaman efektif tanah dan kelas lereng (S3rs) juga dijumpai pada area kajian, yaitu Tabel 4 Hasil analisis kesesuaian lahan untuk taman

\begin{tabular}{|c|c|c|c|c|}
\hline No. & Kelas kesesuaian & Luas (ha) & Luas (\%) & Keterangan \\
\hline 1 & S3r-1 & 2116.08 & 73.12 & $\begin{array}{c}\text { Sesuai marjinal dengan faktor pembatas } \\
\text { tekstur tanah }\end{array}$ \\
\hline 2 & S3r-1.s & 509.22 & 17.60 & $\begin{array}{c}\text { Sesuai marjinal dengan faktor pembatas } \\
\text { tekstur tanah dan lereng }\end{array}$ \\
\hline 3 & S3r-2 & 146.94 & 5.08 & $\begin{array}{c}\text { Sesuai marjinal dengan faktor pembatas } \\
\text { drainase tanah }\end{array}$ \\
\hline 4 & S3r-2.s & 0.60 & 0.02 & $\begin{array}{c}\text { Sesuai marjinal dengan faktor pembatas } \\
\text { drainase tanah dan lereng }\end{array}$ \\
\hline \multirow[t]{2}{*}{5} & $\mathrm{~N}$ & 121.20 & 4.19 & Tidak sesuai \\
\hline & Jumlah & 2894.04 & 100.00 & \\
\hline
\end{tabular}

Tabel 5 Hasil analisis kesesuaian lahan untuk hutan kota

\begin{tabular}{|c|c|c|c|c|}
\hline No. & Kelas kesesuaian & Luas (ha) & Luas (\%) & Keterangan \\
\hline 1 & S3r & 1522.10 & 52.59 & $\begin{array}{l}\text { Sesuai marjinal dengan faktor pembatas kedalaman } \\
\text { efektif tanah }\end{array}$ \\
\hline 2 & S3er & 846.25 & 29.24 & $\begin{array}{l}\text { Sesuai marjinal dengan faktor pembatas kedalaman } \\
\text { efektif tanah dan kepekaan terhadap erosi }\end{array}$ \\
\hline 3 & S3rs & 48.44 & 1.67 & $\begin{array}{l}\text { Sesuai marjinal dengan faktor pembatas kedalaman } \\
\text { efektif tanah dan lereng }\end{array}$ \\
\hline 4 & S3ers & 68.95 & 2.38 & $\begin{array}{l}\text { Sesuai marjinal dengan faktor pembatas kedalaman } \\
\text { efektif tanah, kepekaan terhadap erosi, dan lereng }\end{array}$ \\
\hline \multirow[t]{2}{*}{5} & $\mathrm{~N}$ & 408.30 & 14.12 & Tidak sesuai \\
\hline & Jumlah & 2894.04 & 100.00 & \\
\hline
\end{tabular}




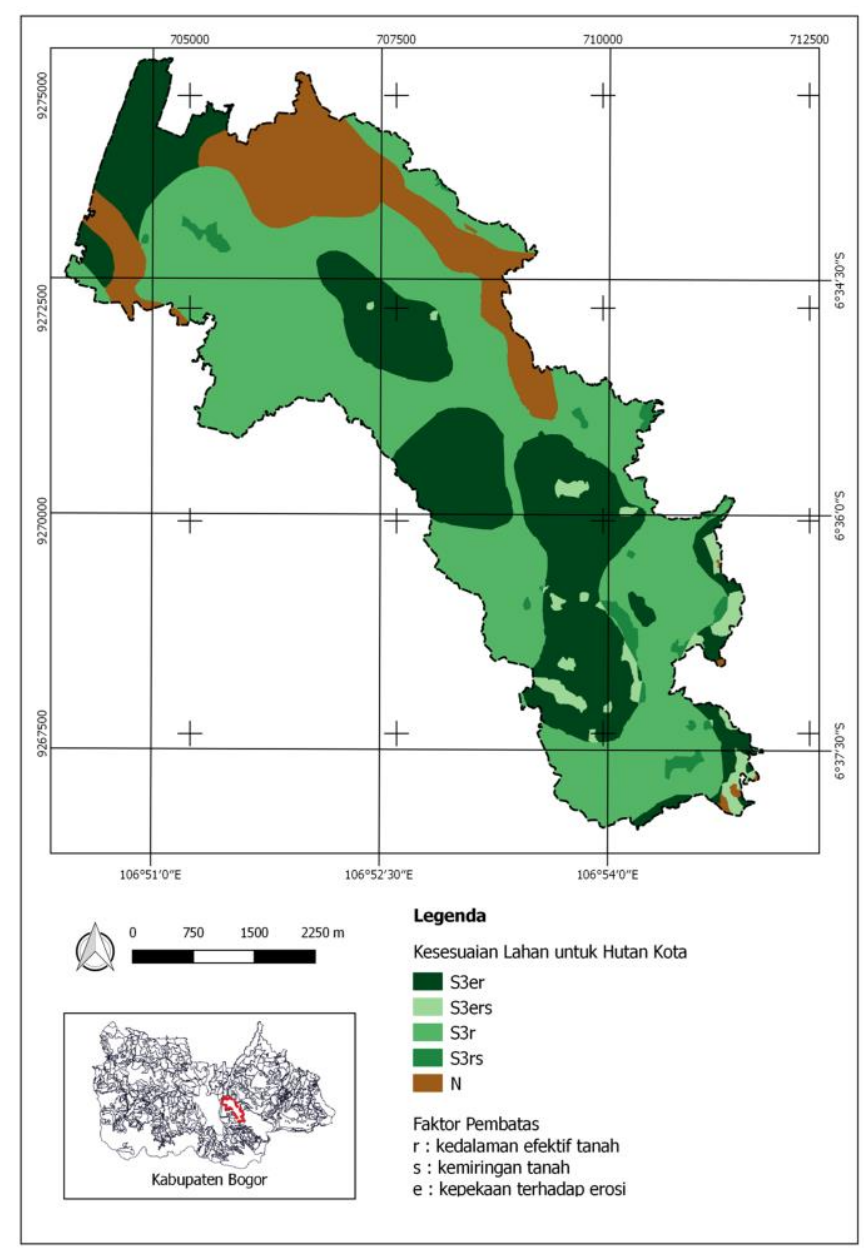

Gambar 3 Peta kesesuaian lahan untuk hutan kota

seluas 48.44 ha $(1.67 \%)$. Lahan ini berada pada kemiringan lahan 25-45\%. Kelas lahan S3ers adalah kelompok lahan yang memiliki faktor pembatas kurang peka terhadap erosi, kedalaman efektif tanah sedang maupun dangkal, dan berada pada kemiringan lahan 25$45 \%$. Kelas lahan ini terdapat seluas 68.95 ha $(2.38 \%)$. Lahan yang tidak sesuai untuk hutan kota $(\mathrm{N})$ adalah sebesar 408.30 ha $(14.00 \%)$, berada di sepanjang sungai yang memiliki tanah tidak peka terhadap erosi dan pada area dengan kemiringan lahan lebih dari 45\% (Tabel 5). Dengan demikian, lahan yang potensial sebagai hutan kota adalah kelas lahan S3r, dengan upaya perbaikan berupa pengolahan tanah.

\section{Analisis Kesesuaian Kesesuaian Lahan untuk Danau}

Berdasarkan kriteria kelas kesesuaian lahan tersebut dilakukan analisis kesesuaian lahan di Sentul City untuk danau buatan di kawasan perkotaan. Hasil analisis menunjukkan bahwa terdapat lahan yang sangat sesuai (S1), cukup sesuai (S2), sesuai marjinal (S3), dan tidak sesuai (N) (Gambar 4). Lahan yang sangat sesuai (S1) adalah sebesar 107.04 ha $(3.70 \%)$. Lahan yang cukup sesuai terbagi ke dalam tiga kelas. Lahan yang cukup sesuai dengan faktor pembatas kelas lereng (S2s) adalah

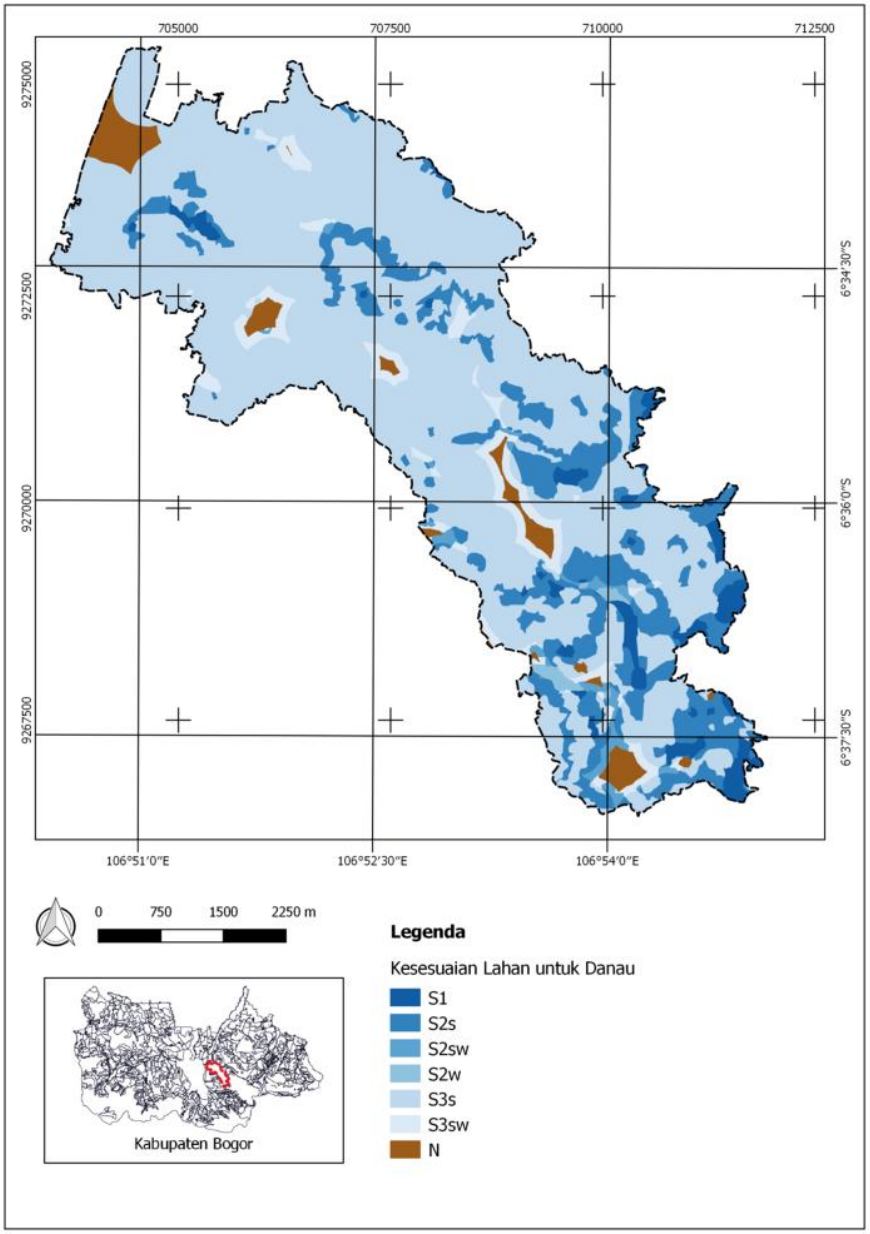

Gambar 4 Peta kesesuaian lahan untuk danau

seluas 460.87 ha $(15.92 \%)$. Lahan yang cukup sesuai dengan faktor pembatas jarak dengan sungai (S2w) adalah seluas 14.15 ha $(0.49 \%)$. Lahan yang cukup sesuai dengan faktor pembatas kelas lereng dan jarak dengan sungai (S2sw) adalah seluas 39.08 (1.35\%). Lahan yang sesuai marjinal terdiri atas dua kelas. Lahan yang sesuai marjinal dengan faktor pembatas kelas lereng (S3s) adalah seluas 2049.92 ha $(70.83 \%)$. Lahan tersebut berada pada kemiringan lereng $2^{\circ}-5^{\circ}$. Lahan yang sesuai marjinal dengan faktor pembatas kelas lereng dan jarak dengan sungai adalah seluas 131.75 ha (4.55\%). Terdapat lahan yang tidak sesuai seluas 91.23 ha (3.15\%) karena berjarak lebih dari 500 meter dengan sungai utama maupun anak sungai (Tabel 6). Dengan demikian, lahan S1 menjadi prioritas utama lahan yang dapat dimanfaatkan sebagai danau buatan yang direkomendasikan.

Hingga saat ini, Sentul City telah mengembangkan dua buah danau buatan, yaitu Danau Telaga Indah dan Danau Teratai. Danau Telaga Indah berlokasi di dalam cluster perumahan, sedangkan Danau Teratai di area komersial yaitu di dekat perkantoran di pinggir jalan utama. Danau Telaga Indah berada pada lahan yang merupakan lembah, titik pertemuan antara kontur datar 
dan curam, sedangkan Danau Teratai berada pada wilayah datar. Danau Telaga Indah diletakkan di daerah yang dilewati sungai, sedangkan Danau Teratai ditempatkan di pinggir jalan utama yang dekat dengan sungai. Kedua danau tersebut berada pada lahan dengan kedalaman efektif tanah 60-90 cm. Penggunaan lahan sekitar Danau Telaga Indah merupakan perumahan dan di sekeliling danau merupakan RTH berupa halaman rumput pada daerah datar dan vegetasi tegakan pohon pada daerah curam. Penggunaan lahan di sekitar Danau Teratai adalah perkantoran dan di sekeliling danau merupakan taman kecil dengan jalan setapak dan terdapat fasilitas tempat duduk di beberapa titik. Berbeda dengan danau buatan yang telah ada, penelitian ini merekomendasikan penambahan danau buatan pada daerah yang not saleable, yaitu diutamakan pada lahan dengan kemiringan besar.

\section{SIMPULAN}

Berdasarkan hasil penelitian, diketahui bahwa lahan yang sesuai marjinal untuk taman kota adalah sebesar $95.81 \%$, sedangkan lahan yang tidak sesuai adalah sebesar $4.19 \%$. Dari lahan tersebut, lahan yang sesuai marjinal untuk taman kota dengan faktor pembatas paling mudah untuk diatasi adalah lahan dengan faktor pembatas drainase tanah (S3r-2) dengan luas 5.08\%, dan diikuti dengan lahan dengan faktor pembatas berupa tekstur tanah (S3r-1) dengan luas $73.12 \%$. Lahan yang sesuai marjinal untuk hutan kota adalah sebesar $85.88 \%$, sedangkan lahan yang tidak sesuai adalah sebesar $14.12 \%$. Lahan yang memiliki faktor pembatas paling mudah untuk diatasi adalah lahan dengan faktor pembatas kedalaman efektif tanah (S3r) dengan luas $52.59 \%$. Lahan yang sangat sesuai untuk danau adalah sebesar $3.70 \%$, sedangkan lahan yang tidak sesuai adalah sebesar $3.15 \%$. Potensi lahan kelas S1 dengan luas $3.70 \%$ dapat menjadi prioritas utama untuk pembuatan danau buatan yang direkomendasikan.

\section{DAFTAR PUSTAKA}

Asdak C. 1995. Hidrologi dan Pengelolaan Daerah Aliran Sungai. Yogyakarta (ID): Gadjah Mada University Press.

[Bappeda] Badan Perencanaan dan Pembangunan Daerah Pemerintah Kabupaten Bogor (ID). Rencana Tata Ruang Wilayah Kabupaten Bogor 2005-2025. Bogor (ID): Bappeda Kabupaten Bogor.

[BMKG] Badan Meteorologi Klimatologi dan Geofisika (ID). 2016. Buletin Analisis Hujan Bulan Maret 2016 dan Prakiraan Hujan Bulan Mei, Juni, dan Juli 2016. BMKG (ID): Stasiun Klimatologi Darmaga Bogor.

[BSNI] Badan Standardisasi Nasional (ID). 2002. Standar Nasional Indonesia: Penyusunan Neraca Sumber Daya - Bagian 1 Sumber Daya Air Spasial [Internet]. [diunduh 2017 Agustus 27]. Tersedia pada: www.bakosurtanal.go.id/assets/download/sni/SN I/SNI\%2019-6728.1-2002.pdf.

Hanafiah KA. 2005. Dasar-dasar Ilmu Tanah. Jakarta (ID): PT Raja Grafindo Persada.

Hardjowigeno S, Widiatmaka. 2007. Evaluasi Kesesuaian Lahan dan Perencanaan Tataguna Lahan. Yogyakarta (ID): Gadjah Mada University Pr.

Kodoatie RJ, Sjarief R. 2008. Pengelolaan Sumber Daya Air Terpadu (Edisi Revisi). Yogyakarta (ID): Andi.

Tumbo SD, Mbilinyi BP, Mahoo HF. 2014. Identification of Suitable Indices for Identification of Potential Sites for Rainwater Harvesting. Tanzania Journal of Agricultural Science. 12(2):35-46.

Ruliyansyah A. 2009. Analisis Kebutuhan Hutan Kota untuk Menjaga Ketersediaan Air di Kota Sintang [Tesis]. Bogor (ID): Institut Pertanian Bogor.

Sentul City (ID). 2011. Masterplan 2465 Ha Sentul City (Revisi). Bogor (ID): PT Sentul City Tbk.

Sentul City (ID). 2012. ANDAL Sentul City. Bogor (ID): PT Sentul City Tbk.

Wong THF, Alien R, Brown RR, Deletic A, Gangadharan L, Gernjak W, Jakob C, Johnstone P, Reeder M, Tapper N, Vietz G, Waish CJ. 2013. Blueprint 2013: Stormwater Management in a Water Sensitive City. Melbourne (AU): Cooperative Research Centre for Water Sensitive Cities.

Wright M. 2015. Rainwater Park: Stormwater Management and Utilization in Landscape Design. Victoria (AU): Images Publishing. 